\title{
Role of microphytobenthos and denitrification for nutrient turnover in embayments with floating macroalgal mats: a spring situation
}

\author{
Kristina Sundbäck*, Alison Miles \\ Department of Marine Ecology, Marine Botany, Göteborg University, PO Box 461, 40530 Göteborg, Sweden
}

\begin{abstract}
The importance of the microphytobenthos (MPB) for nutrient turnover was studied in 2 shallow bays on the west coast of Sweden, during the period that floating green macroalgal mats generally become established in the area. Sediment-water nutrient fluxes (N, P and $\mathrm{Si}$ ) and oxygen fluxes and denitrification were measured in light and dark laboratory incubations prior to and during the early growth of green-algal mats (April to June). The importance of microphytobenthic activity and hence, trophic status of the sediment system, magnitude of sediment fluxes and presence of macroalgal mats were shown to differ between the 2 bays. On a daily basis, the MPB decreased the efflux of inorganic N by 30 to $100 \%$, P by 70 to $100 \%$ and Si by 10 to $95 \%$. Thus, the MPB appears to efficiently control the availability of sediment-derived nutrients to ephemeral green algae during the period that is critical for the onset of the macroalgal growth. The MPB may even depress the development of green-algal mats, providing that these depend on the sediment nutrient efflux. Microphytobenthic $\mathrm{N}$-assimilation was compared with other $\mathrm{N}$-consuming processes, such as denitrification and green-macroalgal $\mathrm{N}$-assimilation. In autotrophic sediments, the MPB was the dominating $\mathrm{N}$-consuming component ( 1 to $\left.5.3 \mathrm{mmol} \mathrm{N} \mathrm{m}^{-2} \mathrm{~d}^{-1}\right)$, denitrification ( 0.1 to $\left.0.7 \mathrm{mmol} \mathrm{N} \mathrm{m}^{-2} \mathrm{~d}^{-1}\right)$ being a minor N-sink. In the net heterotrophic sediments, however (with no or little net MPB productivity, higher infaunal biomass and hence larger nutrient effluxes), green macroalgal growth was the main $\mathrm{N}$-incorporating process (mean $2.3 \mathrm{mmol} \mathrm{N} \mathrm{m} \mathrm{m}^{-1}$ ). This was followed by denitrification ( 0.3 to $1.4 \mathrm{mmol} \mathrm{N} \mathrm{m}^{-2} \mathrm{~d}^{-1}$ ), which removed roughly $20 \%$ of the remineralised $\mathrm{N}$. Thus, denitrification may be a significant $\mathrm{N}$-sink in bays harbouring green-algal mats on the west coast of Sweden.
\end{abstract}

KEY WORDS: Sediment · Microphytobenthos · Nitrogen · Denitrification - Macroalgal mats · Sediment-water fluxes

\section{INTRODUCTION}

Extensive coverage of shallow-water coastal areas by floating macroalgal mats is an increasing phenomenon worldwide, being generally interpreted as a symptom of coastal eutrophication (Valiela et al. 1997, Pihl et al. 1999 and references therein). So far, most studies dealing with the problem of fast-growing macroalgae have focused on the impact of established mats on

*Email: kristina.sundback@marbot.gu.se populations of other organisms or on the function of local food webs (e.g. Isaksson et al. 1994, Rafaelli 2000, Österling \& Pihl 2001 and references therein). Established macroalgal mats have also been studied with regard to competition between these mats and other primary producers of shallow embayments. Mats of fast-growing macroalgae tend to outcompete benthic primary producers, as well as phytoplankton (e.g. Sundbäck et al. 1990, Fong et al. 1993, den Hartog 1994, Havens et al. 2001). Here, we have switched the angle of approach, focusing on the influence that other local primary producers might have on the onset and 
early growth of the macroalgal blooms rather than studying the effect of macroalgal mats themselves.

The sediment is known to function as an important source of regenerated nutrients for maintaining the growth of the macroalgal mats once they have become established (Thybo-Christesen et al. 1993, Jeffrey et al. 1995, Viaroli et al. 1996). However, the actual onset of the macroalgal growth may also be controlled by the local sediment nutrient efflux, rather than, for example, land run-off to the water column. This accords with the idea that embayments may have become, after several decades of nutrient loading, self-regenerating systems that favour the growth of opportunistic macroalgae (Hodgkin \& Birch 1986, Pihl et al. 1999).

In this context, the role of microphytobenthos (MPB) as a competitor and controller of nutrient fluxes across the sediment-water interface (for references see Thornton et al. 1999, Sundbäck et al. 2000) is particularly interesting for several reasons. In contrast to seagrasses and ephemeral macroalgae, which start to grow in spring (Risgaard-Petersen et al. 1998, Pihl et al. 1999), the MPB is present and active throughout the year in temperate northern waters (Rysgaard et al. 1995, Sundbäck et al. 2000). Therefore, as the MPB is already well established at the time of initial macroalgal growth (spring), the MPB can be assumed to compete with the macroalgal mats for the sediment nutrient pool. By forming dense microbial mats at the sediment-water interface, the MPB could 'shut off' the sediment nutrient supply to the water column, thereby counteracting the development of extensive greenalgal mats. This has been proposed in previous experiments (Sundbäck et al. 1996). The same study suggested that benthic diatom mats may continue to thrive under the 'shading roof' of macroalgal mats, thereby extending the controlling effect of MPB on the sediment-water nutrient flux further into the growth season of the ephemeral macroalgae.

The first aim of our study was to assess the role of the MPB in nutrient turnover in shallow embayments, prior to and during the onset of green-macroalgal blooms in the spring. Extended occurrence of filamentous macroalgae on the west coast of Sweden has occurred since the 1970 s, paralleled with an increasing load of nutrients to the coastal zone (Pihl et al. 1996 and references therein). Macroalgal mats begin to develop in May and have been found to cover between 30 and $50 \%$ of the shallow soft-sediment habitats during summer (Pihl et al. 1996, 1999). The working hypothesis was that if the sediment nutrient efflux was critical for the initiation of the growth of the macroalgal mats, then the magnitude of microphytobenthic activity could be an important factor controlling the early growth of the macroalgae. In other words, could the MPB reduce the sediment-nutrient efflux to such a degree that macroalgal growth would be prevented or delayed?

A second aim was to compare the quantitative importance of microphytobenthic nitrogen (N) assimilation and retention with other $\mathrm{N}$-consuming processes, such as macroalgal $\mathrm{N}$-assimilation and the final removal of $\mathrm{N}$ by denitrification. The approach taken was to measure sediment-water nutrient and oxygen fluxes as well as denitrification, prior to and during the early growth phase of the macroalgal mats (April to June) in 2 shallow embayments on the Swedish west coast where green-algal mats commonly occur.

\section{MATERIALS AND METHODS}

Study sites and sampling protocol. Two shallow brackish-water bays on the microtidal (tidal amplitude ca. $20 \mathrm{~cm}$ ) west coast of Sweden, Rågårdsvik (R $\AA_{;}$ $\left.58^{\circ} 12^{\prime} \mathrm{N}, 11^{\circ} 27^{\prime} \mathrm{E}\right)$ and Bassholmen $\left(\mathrm{BA}^{\circ} 58^{\circ} 15^{\prime} \mathrm{N}\right.$, $11^{\circ} 30^{\prime} \mathrm{E}$ ), were studied. These 2 bays were chosen on the basis of a previous study (Pihl et al. 1996, 1999) as being representative of bays that regularly harbour extensive green-algal mats. Characteristics for the sites are given in Table 1 . The study was conducted from 10 April to 28 June 2000. In each bay, 3 stations (20 m apart) were established and at each station, 2 replicate sediment cores were sampled with a $24 \mathrm{~cm}$ long Plexiglas core $(8 \mathrm{~cm}$ in diameter) for incubation measurements. Fluxes of oxygen and inorganic nutri-

Table 1. Characteristics of the 2 bays during the study period (April to June 2000). Either range and/or mean is given. WW: wet weight; DW: dry weight

\begin{tabular}{|lcc|}
\hline & Rågårdsvik & Bassholmen \\
\hline Water column & & \\
Water depth $(\mathrm{m})$ & 0.5 & 0.5 \\
Salinity (PSU) & $8-27(22)$ & $19-26(22)$ \\
Water temperature $\left({ }^{\circ} \mathrm{C}\right)$ & $6-18$ & $6-18$ \\
$\mathrm{NH}_{4}(\mu \mathrm{M})$ & $0.6-4.4(2.2)$ & $0.8-3.9(1.8)$ \\
$\mathrm{NO}_{3}+\mathrm{NO}_{2}(\mu \mathrm{M})$ & $0.2-21.2(3.9)$ & $0.2-3.5(0.86)$ \\
$\mathrm{PO}_{4}(\mu \mathrm{M})$ & $0.1-0.6(0.4)$ & $0.1-0.6(0.4)$ \\
$\mathrm{Si}(\mathrm{OH})_{4}(\mu \mathrm{M})$ & $2-71(14.8)$ & $2-10(4.5)$ \\
Sediment & & \\
Porosity & 0.81 & 0.65 \\
$\mathrm{C}-$ content $(\%)$ & 2.04 & 0.16 \\
$\mathrm{~N}$-content $(\%)$ & 0.23 & $20-131(73)$ \\
Infaunal biomass $\left(\mathrm{g} \mathrm{WW} \mathrm{m}{ }^{-2}\right)$ & $18-59(35)$ & \\
Green-algal mat & & \\
Biomass (g DW m $\left.{ }^{-2}\right)$ & 0 & \\
a Value for June & & \\
\hline
\end{tabular}


ents ( $\mathrm{N}, \mathrm{P}$ and $\mathrm{Si}$ ) were measured in light and dark under controlled laboratory conditions (see below). Chlorophyll $a$ ( $\mathrm{chl}$ a) and sediment properties were also measured (see Table 1 and 'Sediment properties'). Biomass of macroscopic infauna was measured in the top $5 \mathrm{~cm}$ (mesh size $0.5 \mathrm{~mm}$ ). Incubations were run on 4 occasions, during calendar Weeks 15 (midApril), 19 (mid-May), 24 (mid-June) and 26 (end of June). These sampling periods will be referred to as W15, W19, W24 and W26, respectively. Nutrient concentrations in the in situ overlying water were measured weekly from April to the end of June. Biomass, growth rate and $\mathrm{N}$-content of green-algal mats were monitored during the study period (Sundbäck et al. in press). At BA, green-algal mats (dominated by Enteromorpha spp.) began to develop in May, reaching a mean biomass of $40 \mathrm{~g} \mathrm{DW} \mathrm{m}{ }^{-2}$ by the middle of June. No green-algal mats developed at RÅ during the study period.

Flux measurements. Sediment incubations for nutrient $\left(\mathrm{NH}_{4}{ }^{+}, \mathrm{NO}_{3}{ }^{-}+\mathrm{NO}_{2}{ }^{-}, \mathrm{PO}_{4}{ }^{3}\right)$ and oxygen fluxes were carried out in the laboratory in light and dark. Two replicate and 1 blank core (only site water) for each station were incubated with magnetic stirring ( $60 \mathrm{rpm})$ at in situ temperature in specially designed tanks containing circulating site water (for details see Dalsgaard et al. 2000, Sundbäck et al. 2000). Light level during the incubation (individual $25 \mathrm{~W}$ halogen bulbs over each core) was adjusted to the daily mean (i.e. the mean for the time from sunrise to sunset) for that month. Incubation time was set so that changes in oxygen concentration within the cores did not exceed $20 \%$ and varied between 1.5 and $5 \mathrm{~h}$, depending on temperature. Oxygen concentrations were measured using Winkler titration. Nutrient samples were immediately frozen $\left(-80^{\circ} \mathrm{C}\right)$ and stored until analysis, which followed standard colorimetric methods using autoanalyser (TRAACS, Braun-Lubbe). As the sediment cores were exposed to a mean daily light level, oxygen and nutrient fluxes were recalculated to daily values using the number of light and dark hours obtained from a DELTA-T light sensor at the Kristineberg Marine Research Station.

Calculation of algal assimilation of nutrients. Microphytobenthic nutrient assimilation was calculated from daily net oxygen flux in light (net productivity, NP) and gross production (GP = the sum of NP and community respiration [CR] in the dark). For practical reasons, it was assumed that community respiration in the light equalled respiration in the dark. For conversion of oxygen to carbon produced, a photosynthetic quotient (PQ) of 1.2 was assumed (Wetzel \& Likens 1991). N-assimilation by the MPB was calculated assuming a C:N molar ratio of 9 (Sundbäck et al. 2000 and references therein). The retention of $\mathrm{N}$ in the MPB biomass was estimated from sediment chl a values, assuming a mean C:chl a ratio of 30 (de Jonge 1980, Sundbäck et al. 2000). Mean green macroalgal Nassimilation and retention were estimated from net macroalgal growth and the $\mathrm{N}$ and $\mathrm{P}$ content of the algae. Macroalgal growth (dry weight $[D W] \mathrm{m}^{-2} \mathrm{~d}^{-1}$ ) was calculated from the initial increase of algal biomass (5 replicate random samples of $350 \mathrm{~cm}^{2}$ ) between W19 and W24. As turnover or loss rates were not measured, the mean net growth represents a conservative estimate of mean biomass increase and nutrient accumulation in algal biomass.

Denitrification. Denitrification was measured in light and dark in the same laboratory incubation set-up that was used for flux measurements, using the isotope pairing technique (Nielsen 1992), which discriminates between denitrification supported by $\mathrm{NO}_{3}$ in the water column $\left(D_{\mathrm{w}}\right)$ and nitrification-coupled denitrification $\left(D_{\mathrm{n}}\right) .{ }^{15} \mathrm{NO}_{3}\left(40 \mathrm{mM} \mathrm{Na}{ }^{15} \mathrm{NO}_{3}, 99.6\right.$ at. \%, Europa Scientific) was added to the headspace water in the cores to a final concentration corresponding to ca. $20 \%$ of the oxygen concentration (50 to $90 \mu \mathrm{M}{ }^{15} \mathrm{NO}_{3}$ ). The isotopic ${ }^{15} \mathrm{~N}:{ }^{14} \mathrm{~N}$ ratio of $\mathrm{N}_{2}$ was analysed by mass spectrometry at the National Environmental Research Agency, Silkeborg, Denmark. Daily rates of total denitrification $\left(D_{\mathrm{tot}}=D_{\mathrm{w}}+D_{\mathrm{n}}\right)$ were calculated by multiplying the hourly rate in light by the number of daylight hours and the hourly rate in the dark by the number of dark hours. The total amount of $\mathrm{N}$ removed by denitrification during the 3 mo study period (April to June) was calculated by multiplying daily values by the number of days in the month. For June, the mean value of the 2 occasions (W24 and W26) was used.

Sediment properties. Samples for chl $a$ and pheopigment content of the top $5 \mathrm{~mm}$ sediment were taken from the sediment cores, on completion of the nutrient flux measurements, with a $20 \mathrm{ml}$ cut-off disposable syringe. The samples were immediately frozen $\left(-80^{\circ} \mathrm{C}\right)$. Pigment concentration was measured spectrophotometrically (Lorenzen 1967) after extraction with $90 \%$ acetone. The composition of the MPB was assessed semi-quantitatively using epifluorescence microscopy. Porosity of the top $5 \mathrm{~mm}$ of sediment was measured by gravimetric standard methods (e.g. Dalsgaard et al. 2000). The content of particulate organic carbon (POC) and nitrogen (PON) of the sediment was determined on dried samples using a Carlo Erba CHN elemental analyser. Before analysis, samples for POC content were treated with $\mathrm{HCl}$ fumes to remove metal carbonates.

Statistical analyses. Spatial variation was tested using 3-way nested ANOVA with time, bay and station (nested within bays) as factors. As no significant differences between stations within a bay were found, further testing of treatments was based on 6 replicates. 
Differences between fluxes in light and dark were tested using a 2-way ANOVA, with time and treatment as factors. Homogeneity of variances was checked using Cochran's test and when found to be heterogeneous, the data were transformed according to Underwood (1997). In cases of a significant interaction term, pair wise comparisons of the means were made using Student-Newman- Keul's test (SNK). Differences were accepted as significant at $\mathrm{p}<0.05$.

\section{RESULTS}

\section{Microphytobenthic biomass and composition}

Mean chl a content of the top $5 \mathrm{~mm}$ sediment varied only slightly during the 3 mo study period (range 61 to $137 \mathrm{mg} \mathrm{m}^{-2}$ ), being occasionally (W15 and W24) different between the 2 bays (week $\times$ bay interaction, $\mathrm{p}=$ 0.0001) (Fig. 1a). Pheopigment concentrations (range 40 to $92 \mathrm{mg} \mathrm{m}^{-2}$ ) were significantly higher at BA than at RA (Fig. 1a). Epifluorescence microscopy revealed a well-developed community consisting of both motile and epipsammic (attached) diatom species. Dominat- a

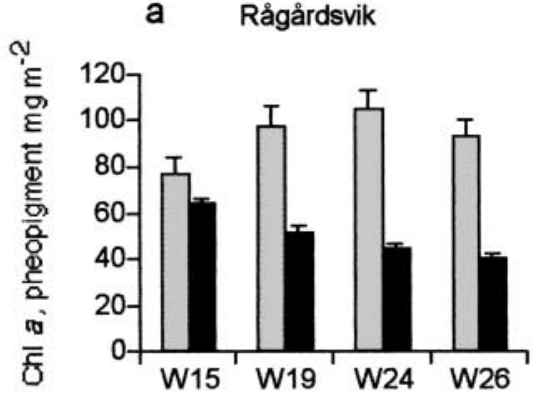

b

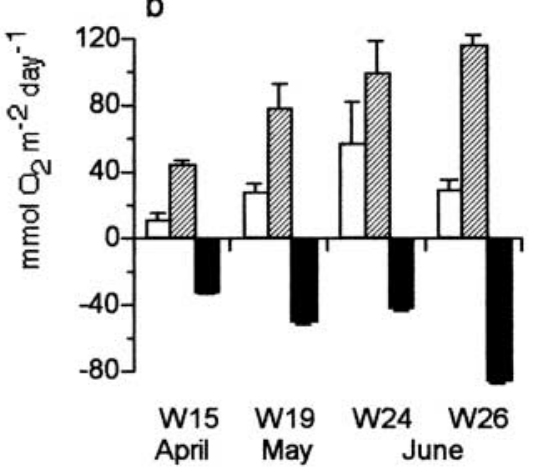

Bassholmen
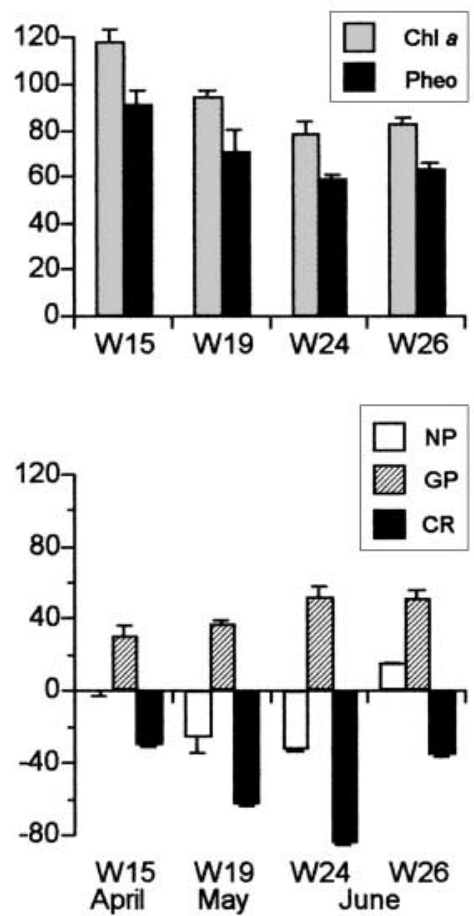

Fig. 1. (a) Chlorophyll $a$ and pheopigment content of the top $5 \mathrm{~mm}$ sediment and (b) daily net (NP) and gross (GP) primary productivity and community respiration (CR) on 4 occasions during April to June 2000 at Rågårdsvik (RÅ) and Bassholmen (BA). Bars show mean $+\mathrm{SE}, \mathrm{n}=6$. Numbers on $X$-axes denote calendar week (W) numbers ing species in both bays during the study period were the centric diatom Paralia sulcata (Ehrenberg) Cleve and sigmoid motile species, such as Gyrosigma fasciola (Ehrenberg) Griffith \& Henfrey, and small Fragilarialike epipsammic cells. In April, Cylindrotheca closterium (Ehrenberg) Reimann \& Lewin, and sedimented chains of the planktonic species Skeletonema costatum (Greville) Cleve, were also common. In June, the number of colonies of the cyanobacterium Microcrocis sp. had increased at both sites.

\section{Oxygen flux}

There was a significant effect of light on the hourly oxygen flux, reflecting MPB primary productivity. Daily GP varied between 30 and $115 \mathrm{mmol} \mathrm{O} \mathrm{m}^{-2} \mathrm{~d}^{-1}$ (equivalent to $300-1150 \mathrm{mg} \mathrm{C} \mathrm{m}^{-2} \mathrm{~d}^{-1}$ ), while NP varied between 0 and $58 \mathrm{mmol} \mathrm{O}_{2} \mathrm{~m}^{-2} \mathrm{~d}^{-1}$ (0 to $580 \mathrm{mg} \mathrm{C}$ $\left.\mathrm{m}^{-2} \mathrm{~d}^{-1}\right)$. From May onwards, both GP and NP were significantly higher at RA than at BA (2-way ANOVA, week $\times$ bay interaction) (Fig. 1b). Net oxygen fluxes showed that RÅ was an autotrophic system during daytime, while BA was heterotrophic, with the exception of late June. CR was within the same range in both bays (30 to $86 \mathrm{mmol} \mathrm{O}_{2} \mathrm{~m}^{-2} \mathrm{~d}^{-1}$ ) (Fig. 1b).

\section{Nutrient fluxes}

Water-column concentrations of DIN during the study period were generally below $5 \mu \mathrm{M}$, with the exception of a $\mathrm{NO}_{3}$ peak of $21 \mu \mathrm{M}$ at $\mathrm{R} \AA$ in April (Table 1). $\mathrm{PO}_{4}$ concentrations were low, generally close to the detection limit (Table 1). Si content (range 2 to $71 \mu \mathrm{M})$ was higher at $\mathrm{R} \AA$ than BA.

Three general patterns emerged from the hourly nutrient fluxes: (1) light had a significant effect on the fluxes (Table 2); (2) effluxes were significantly higher at BA than at $R \AA$, where frequent net uptake occurred; and (3) fluxes increased significantly between April and May, coinciding with a temperature increase of $10^{\circ} \mathrm{C}$ (Fig. 2).

Light had a significant effect on $\mathrm{NH}_{4}$ and $\mathrm{NO}_{3}$ fluxes in both bays (Table 2). At RA, $\mathrm{NH}_{4}$ was taken up by the sediment in the light and released in the dark, with the exception of May (Fig. 2a). At BA, $\mathrm{NH}_{4}$ was released, although the efflux decreased by 40 to $60 \%$ in the light (Fig. 2a). Nitrate fluxes were low $\left(<10 \mu \mathrm{mol} \mathrm{m} \mathrm{m}^{-2} \mathrm{~h}^{-1}\right)$ at $\mathrm{R} \AA$, but increased to greater than $100 \mu \mathrm{mol}$ at BA 
Table 2. Results of 2-way ANOVA testing the significance of light on hourly sediment nutrient fluxes and denitrification rates. Factors used were week (W) and light/dark treatment (L/D). Probability (p) values for either an overall single-factor effect of L/D treatment or a $\mathrm{W} \times \mathrm{L} / \mathrm{D}$ interaction are shown. Week number denotes the number of the calendar week when significant effects were found based on Student-Newman-Keul's (SNK) tests, $\mathrm{ns}=$ no significant effects; $\mathrm{n}=6$. DIN = dissolved inorganic nitrogen, $D_{\mathrm{w}}=$ denitrification based on water column $\mathrm{NO}_{3}, D_{\mathrm{n}}=$ nitrification-coupled denitrification

\begin{tabular}{|c|c|c|c|c|c|c|}
\hline \multirow[t]{2}{*}{ Variable } & \multicolumn{3}{|c|}{ Rågårdsvik (RÅ) } & \multicolumn{3}{|c|}{ Bassholmen (BA) } \\
\hline & Factor & $\mathrm{p}$ & Week & Factor & $\mathrm{p}$ & Week \\
\hline $\mathrm{NH}_{4}$ & $\mathrm{~W} \times \mathrm{L} / \mathrm{D}$ & 0.0001 & 19,24 & L/D & 0.0135 & \\
\hline $\mathrm{NO}_{3}+\mathrm{NO}_{2}$ & $\mathrm{~W} \times \mathrm{L} / \mathrm{D}$ & 0.0001 & $15,19,26$ & $\mathrm{~W} \times \mathrm{L} / \mathrm{D}$ & 0.0014 & 24,26 \\
\hline DIN & $\mathrm{W} \times \mathrm{L} / \mathrm{D}$ & 0.0001 & 19,24 & L/D & 0.0001 & \\
\hline $\mathrm{PO}_{4}$ & $\mathrm{~W} \times \mathrm{L} / \mathrm{D}$ & 0.0001 & $15,19,24$ & $\mathrm{~W} \times \mathrm{L} / \mathrm{D}$ & 0.0001 & $19,24,26$ \\
\hline $\mathrm{Si}(\mathrm{OH})_{4}$ & L/D & 0.0257 & & ns & & \\
\hline$D_{\mathrm{w}}$ & L/D & 0.0005 & & ns & & \\
\hline$D_{\mathrm{n}}$ & $\mathrm{W} \times \mathrm{L} / \mathrm{D}$ & 0.0173 & 19 & ns & & \\
\hline
\end{tabular}

(Fig. 2b). When calculated over the day, total fluxes of DIN $\left(\mathrm{NO}_{3}+\mathrm{NO}_{2}+\mathrm{NH}_{4}\right)$ were significantly higher at $\mathrm{BA}$ than at $\mathrm{R} \AA$ from May onwards (2-way ANOVA, week $\times$ bay interaction, $p=0.0002$ ). Thus, at $R \AA$, sediments functioned mainly as a sink of DIN, while at BA sediments functioned as a source of DIN.

Fluxes of $\mathrm{PO}_{4}$ were low and the light effect, although significant (Table 2), did not always follow the usual pattern of less efflux in the light (Fig. 2c). Si showed a significant light/dark effect at $R \AA$, with frequent uptake in light, while no such light effect was seen for BA, the flux being mainly out of the sediment (Table 2, Fig. 2d).

\section{Denitrification}

$D_{\text {tot }}$ varied between ca. 5 and $60 \mu \mathrm{mol} \mathrm{N} \mathrm{m} \mathrm{m}^{-2}$

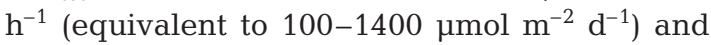
was dominated by $D_{\mathrm{n}}$, which was an order of magnitude higher than $D_{W}$ (Figs. $3 \& 4$ ). Light had a significant effect on denitrification rates at R̊ (Table 2), with an overall negative effect on $D_{\mathrm{w}}$, while $D_{\mathrm{n}}$ was only affected in May. No significant light effect was seen at BA (Table 2, Fig. 3). Daily total denitrification was significantly higher at BA (Fig. 4).

Fig. 2. Sediment-water fluxes of inorganic nutrients $\left(\mathrm{NH}_{4}, \mathrm{NO}_{3}+\mathrm{NO}_{2}, \mathrm{PO}_{4}, \mathrm{Si}[\mathrm{OH}]_{4}\right)$ in light and dark conditions on 4 occasions during April to June 2000 at Rågårdsvik (RÅ) and Bassholmen (BA). Bars show mean $+\mathrm{SE}, \mathrm{n}=6$. Numbers on $x$-axes denote calendar week (W) numbers. The horizontal line indicates the period when macroalgae were present at BA

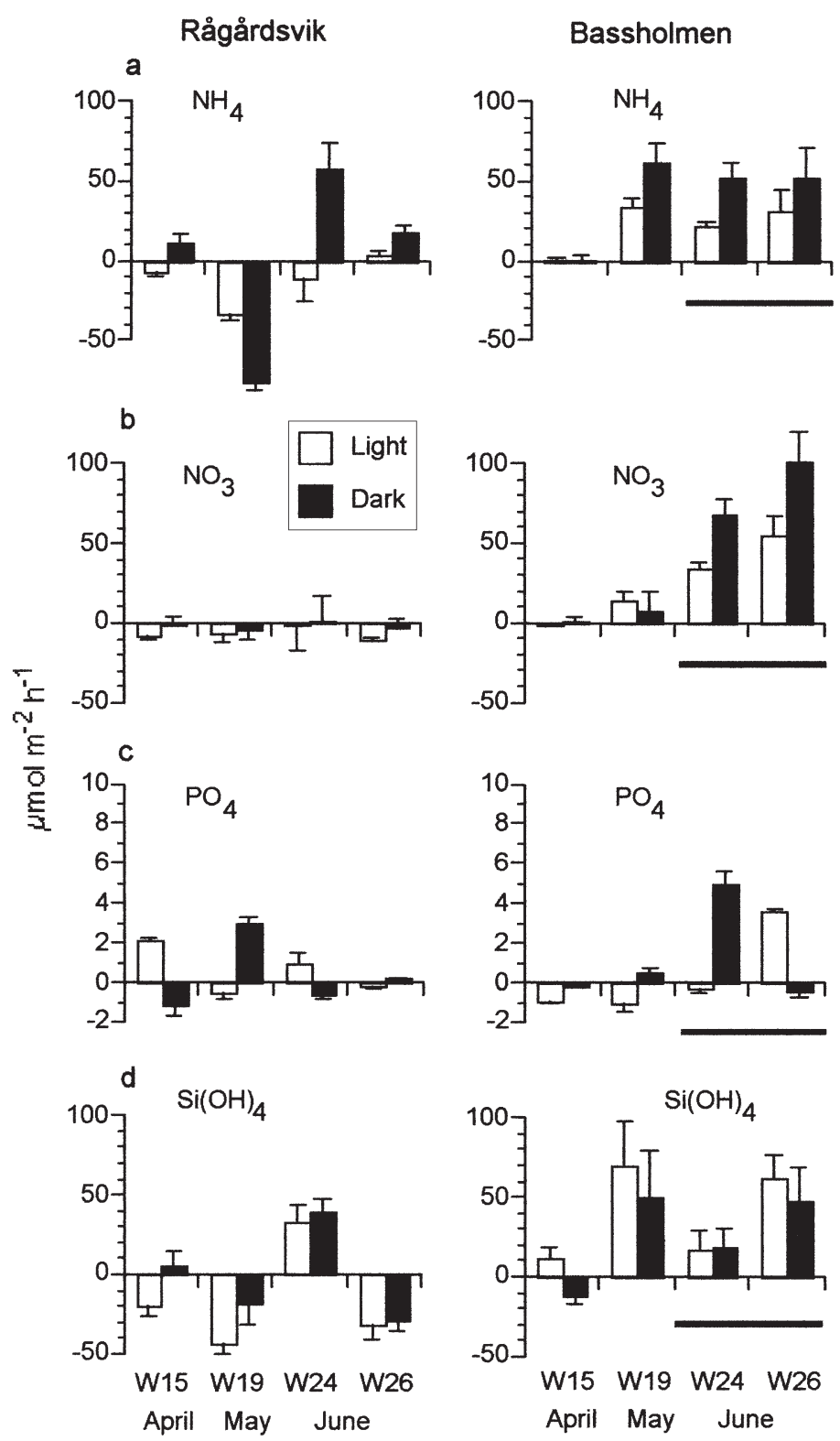




\section{Magnitude of the microphytobenthic effect on nutrient turnover}

Microphytobenthos exerted a significant effect on both nutrient fluxes and denitrification although to a different degree in the 2 bays. The magnitude of microphytobenthic influence on daily nutrient effluxes can be roughly estimated by comparing calculated daily fluxes with a hypothetical $24 \mathrm{~h}$ dark flux. Then, MPB could decrease daily DIN efflux by 40 to $>100 \%$ at RA, but only by 30 to $40 \%$ at BA. Si efflux was decreased by 10 to $95 \%$ at $\mathrm{R} \AA$, whereas no significant decrease was observed at BA. The light effect on $\mathrm{PO}_{4}$ was not consistent at RA. However, at BA microphytobenthos decreased daily $\mathrm{PO}_{4}$ efflux by 70 to $>100 \%$ during the first 3 sampling weeks.

Fig. 4 summarises the magnitude of calculated daily microalgal assimilation of DIN (based on NP and GP, $\mathrm{MPB}_{\mathrm{NP}}$ and $\mathrm{MPB}_{\mathrm{GP}}$, respectively), and $D_{\text {tot }}$ as well as daily fluxes of DIN. At RA, where no green macroalgal growth occurred during the study period, MPB assimilation from $\mathrm{NP}\left(\mathrm{MPB}_{\mathrm{NP}}\right.$ : 1 to $5.3 \mathrm{mmol} \mathrm{N} \mathrm{m} \mathrm{d}^{-2} \mathrm{~d}^{-1}$ was the dominating $\mathrm{N}$-consuming process on a daily basis, denitrification ( 0.1 to $0.7 \mathrm{mmol} \mathrm{N} \mathrm{m}^{-2} \mathrm{~d}^{-1}$ ) having a minor role (Fig. 4a). At BA, on the other hand, macroalgal assimilation was the most important $\mathrm{N}$-consuming process from May onwards (mean $2.3 \mathrm{mmol} \mathrm{N} \mathrm{m}^{-2} \mathrm{~d}^{-1}$ ), followed by denitrification ( $D_{\text {tot }} 0.3$ to $1.4 \mathrm{mmolN} \mathrm{m}^{-2}$ $\mathrm{d}^{-1}$ ), at least when adopting the more conservative measure of $\mathrm{MPB}_{\mathrm{NP}}$. At the end of June, however, $\mathrm{MPB}_{\mathrm{NP}}\left(1.4 \mathrm{mmolN} \mathrm{m} \mathrm{N}^{-2} \mathrm{~d}^{-1}\right)$ equalled denitrification (Fig. 4a).

Two types of daily DIN fluxes are shown in Fig. 4. Measured fluxes, calculated as daily rates (Fig. 4b), suggest that the sediments at RA act mainly as a N-sink, while those at BA act mainly as a N-source. Calculated daily light-related uptake (Fig. 4c), which is the difference between a hypothetical $24 \mathrm{~h}$ dark flux and the daily flux, roughly mirrors the uptake related to microphytobenthic activity and was within the same range for both bays ( 0 to $1150 \mu \mathrm{mol} \mathrm{N} \mathrm{m}{ }^{-2} \mathrm{~d}^{-1}$ ). Light-related uptake at $\mathrm{R} \AA$ corresponded roughly to 20 to $50 \%$ of the calculated microphytobenthic DIN demand (cf. Fig. 4a), while at BA, light-related uptake roughly equalled $\mathrm{MPB}_{\mathrm{NP}}$.

\section{Balance between $\mathbf{N}$-consuming processes}

Table 3 summarises the magnitude of $\mathrm{N}$ consuming components and processes calculated over the 3 mo study period. The 3 pro- cesses include calculated microphytobenthic and macroalgal N-assimilation, and measured total denitrification. For an explanation and calculations of these variables, see Table 3 . The $A: D$ ratio is the balance between algal N-assimilation and N-removal by denitrification (Sundbäck \& Miles 2000). The estimated amounts of $\mathrm{N}$ consumed by the 3 processes were either within the same order of magnitude or they differed, at most, by 1 order of magnitude (Table 3 ). When considering the balance between these processes, we have adopted the more conservative measure of microphytobenthic $\mathrm{N}$-assimilation, i.e. that based on NP $\left(\mathrm{MPB}_{\mathrm{NP}}\right)$.

At $R \AA$, where no green-macroalgal growth occurred, microphytobenthic assimilation consumed most $\mathrm{N}$ (235 mmol m-2), while total denitrification removed only $44 \mathrm{mmol} \mathrm{N} \mathrm{m}^{-2}\left(\approx 20 \%\right.$ of $\left.\mathrm{MPB}_{\mathrm{NP}}\right)$ (Table 3$)$. It is interesting to note that $\mathrm{MPB}_{\mathrm{NP}}$ at $\mathrm{R} \AA$ exceeded, by a factor of 2, the green-macroalgal consumption calculated for BA. At BA, macroalgal assimilation (118 $\mathrm{mmol} \mathrm{N} \mathrm{m}^{-2}$ ) was the dominating $\mathrm{N}$-consuming process, followed closely by denitrification $(87 \mathrm{mmol}$ $\mathrm{m}^{-2}$ ), which in turn exceeded microphytobenthic net
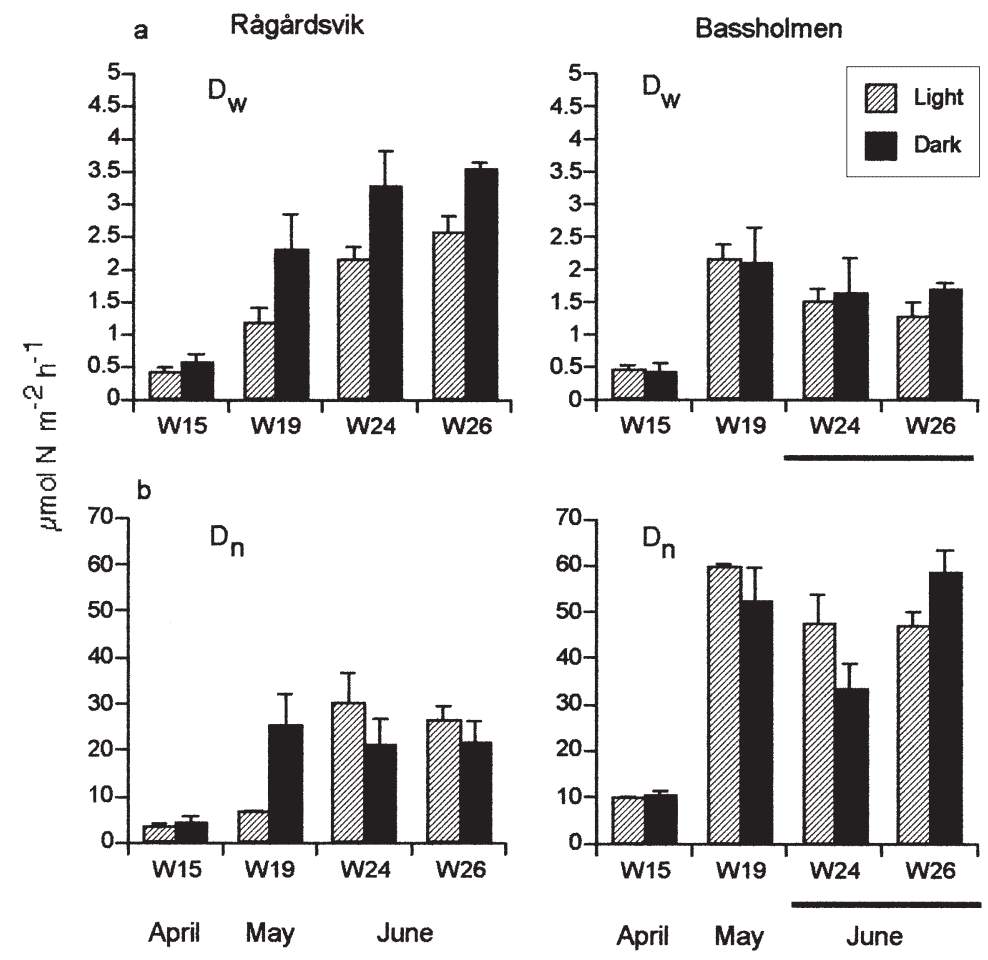

Fig. 3. Denitrification based on water column $\mathrm{NO}_{3}\left(D_{\mathrm{w}}\right)$ and nitrification-coupled denitrification $\left(D_{\mathrm{n}}\right)$ in light and dark conditions on 4 occasions during April to June 2000 at Rågårdsvik (RÅ) and Bassholmen (BA). Bars show mean $+\mathrm{SE}, \mathrm{n}=4$. Numbers on $x$-axes denote calendar week (W) numbers. The horizontal line indicates the period when macroalgae were present at BA 
Table 3. Calculated N-consumption and retention by microphytobenthos (MPB) and green macroalgal mats (MA) and measured denitrification $(D)$ for the period April to June 2000: assimilation by MPB is calculated from gross production (MPB $\left.{ }_{\mathrm{GP}}\right)$ and net production $\left(\mathrm{MPB}_{\mathrm{NP}}\right)$. N retained in MPB biomass is based on mean chlorophyll a $\left(\mathrm{MPB}_{\text {bior }}\right)$, assuming a C:chl a ratio of 30. Assimilation by green algae is based on net growth $\left(\mathrm{MA}_{\mathrm{NP}}\right), \mathrm{N}$ retained in green-macroalgal biomass $\left(\mathrm{MA}_{\text {bio) }}\right)$ is based on mean biomass dry weight (DW) $\mathrm{m}^{-2}$ and measured $\mathrm{N}$ content. Values for green macroalgae are from mid-May to June. Ratios between algal $\mathrm{N}$-assimilation and denitrification $(A: D)$ based on both GP and NP are shown. Consumption rates are expressed as mmol $\mathrm{N} \mathrm{m}^{-2}$ $3 \mathrm{mo}^{-1}$ and retention in biomass as $\mathrm{mmol} \mathrm{N} \mathrm{m}^{-2}$

\begin{tabular}{|c|c|c|c|c|c|c|c|c|c|}
\hline Bay & $\mathrm{MPB}_{\mathrm{GP}}$ & $\mathrm{MPB}_{\mathrm{NP}}$ & $\mathrm{MPB}_{\text {bio }}$ & $\mathrm{MA}_{\mathrm{NP}}$ & $\mathrm{MA}_{\text {bio }}$ & $D$ & $\mathrm{MPB}_{\mathrm{GP}}: D$ & $\begin{array}{l}A: D \text { ratios } \\
\mathrm{MPB}_{\mathrm{NP}}: D\end{array}$ & $\mathrm{MA}_{\mathrm{NP}}: D$ \\
\hline Rågårdsvik (RÅ) & 517 & 235 & 26 & & & 44 & 11.8 & 5.3 & \\
\hline Bassholmen (BA) & 204 & 21 & 26 & 118 & 58 & 87 & 2.3 & 0.24 & 1.4 \\
\hline
\end{tabular}

assimilation (21 $\mathrm{mmol} \mathrm{m}^{-2}$ ) by a factor of $\sim 4$. However, if microphytobenthic assimilation was based on GP $\left(\mathrm{MPB}_{\mathrm{GP}}: 204 \mathrm{mmol}\right.$ $\mathrm{m}^{-2}$ ), it would be double that of denitrification. The $A_{\mathrm{NP}}: D$ ratio for the MPB was ca. 5 for $\mathrm{R} \AA$, but below 1 for $\mathrm{BA}$, emphasising the varying importance of the MPB in the 2 bays that were studied. The $A: D$ ratio for green macroalgae (1.4) suggested that macroalgal assimilation and denitrification were nearly balanced at BA in terms of DIN consumption.

If N-retention is estimated as the amount of $\mathrm{N}$ that at any time is retained in the mean amount of algal standing stock $\left(\mathrm{MPB}_{\text {bio, }} \mathrm{MA}_{\text {bio }}\right.$ in Table 3), we find that approximately double the amount of $\mathrm{N}$ is retained in macroalgae as in the MPB. However, mean standing stock is an underestimation of N-retention, as no attention is paid to the fact that $\mathrm{N}$ is both moved farther in the food web and buried in the sediment.

\section{DISCUSSION}

Although our study is limited, covering only 1 spring period and 2 bays, it provides some indicators regarding the role of the MPB in embayments subjected to eutrophication. The MPB appears to compete successfully for the local sediment pool of regenerated nutrients during the period that is critical for the onset of the green macroalgal growth. At the same time, the role of seemingly similar microphytobenthic communities appears to vary between apparently similar sediment systems and bays.
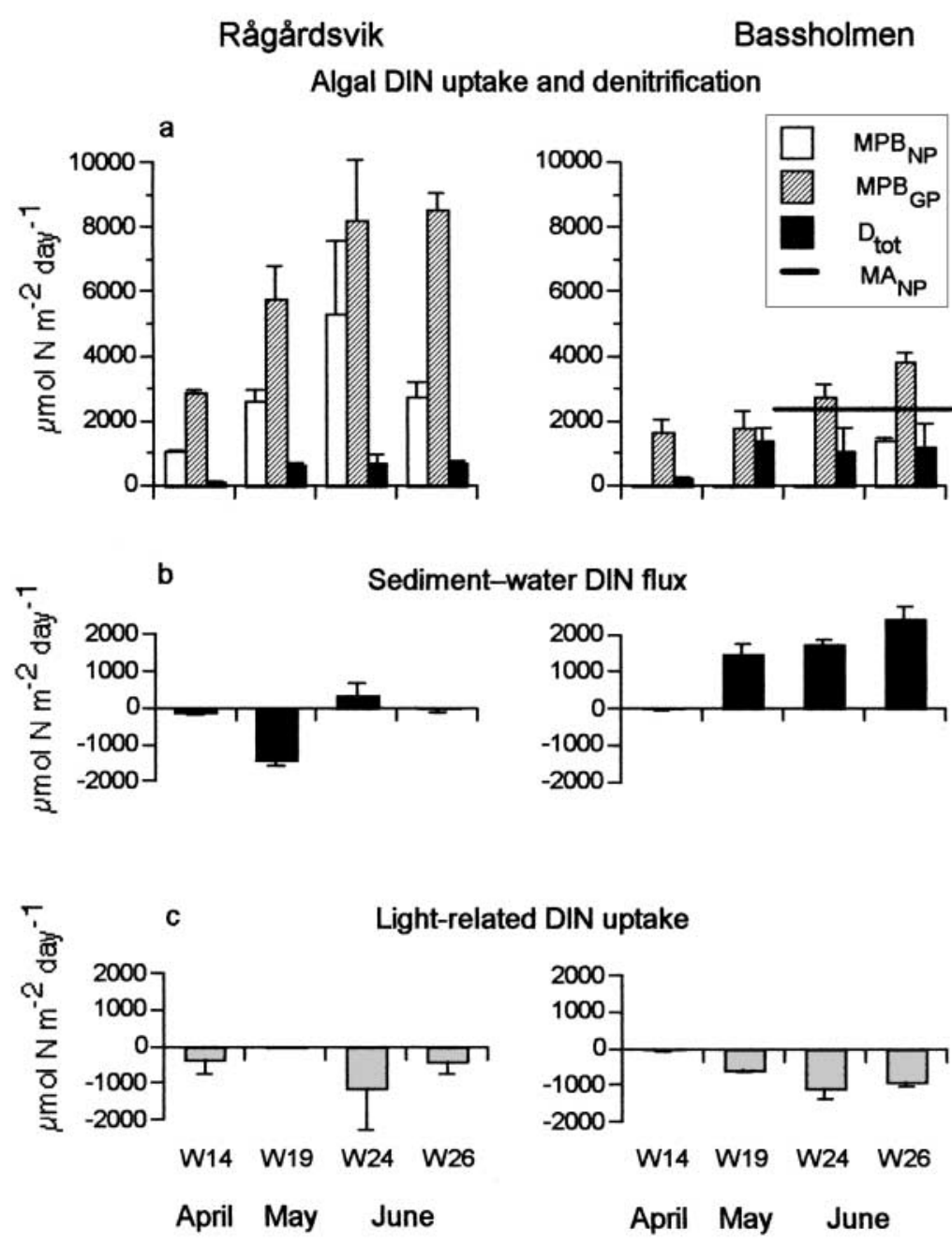

Fig. 4. Importance of microphytobenthic (MPB) N-assimilation, calculated from net productivity $\left(\mathrm{MPB}_{\mathrm{NP}}\right)$ and gross productivity $\left(\mathrm{MPB}_{\mathrm{GP}}\right)$, and measured total denitrification $\left(D_{\text {tot }}\right)$ on 4 occasions during April to June 2000 at Rågårdsvik (RÅ) and Bassholmen (BA). The mean rate of green-macroalgal assimilation at $\mathrm{BA}$, calculated from net growth $\left(\mathrm{MA}_{\mathrm{NP}}\right)$, is indicated by a horizontal line. Bars show mean $+\mathrm{SE}, \mathrm{n}=6$ for $\mathrm{MPB}_{\mathrm{NP}}$ and $\mathrm{MPB}_{\mathrm{GP}}, \mathrm{n}=5$ for $\mathrm{MA}_{\mathrm{NP}}$ and $\mathrm{n}=4$ for denitrification. Numbers on $\mathrm{x}$-axes denote calendar week number 


\section{Light/dark effects on nutrient fluxes and denitrification}

Light significantly decreased sediment effluxes of all nutrients that were measured, although to a different degree in the 2 bays studied. The effect of the MPB on sediment-water nutrient fluxes, through both uptake and oxygenation of the sediment surface, is today well documented for both intertidal and subtidal sediments (e.g. Henriksen et al. 1980, Rizzo 1990, Sundbäck et al. 1991, Reay et al. 1995, Thornton et al. 1999, Cabrita \& Brotas 2000). However, the actual ecological implication of this effect on sediment-water nutrient fluxes has rarely been discussed, although it could be of particular interest in the type of coastal sheltered embayments considered here. Assuming that the MPB was responsible for the main reduction of nutrient efflux from the sediment in light, our results suggest that the activity of MPB could, on occasion, reduce the daily efflux of dissolved inorganic $\mathrm{N}, \mathrm{P}$ and $\mathrm{Si}$ by up to $100 \%$. This would imply that there is no net efflux of regenerated nutrients from the sediment to the water column, a situation that makes green macroalgal growth dependant on external nutrient supply to the water column.

An effect of light exposure was also seen on denitrification, but only in one of the bays (RA). Light effects on denitrification are difficult to interpret, as $D_{\mathrm{w}}$ and $D_{\text {n }}$ may be affected in opposite ways by microphytobenthic activity (Risgaard-Petersen et al. 1994, Dong et al. 2000, An \& Joye 2001). The general effect of light (and MPB), however, appears to be a reduction in denitrification rates, particularly when $\mathrm{NO}_{3}$ values are low (Rysgaard et al. 1995, Sundbäck et al. 2000). A significant effect at R̊, but not at BA, suggests that the competition for $\mathrm{NO}_{3}$ between denitrifiers and MPB was larger at $\mathrm{R} \AA$, which agrees with the higher microphytobenthic activity at RA when compared with BA. $D_{\mathrm{w}}$ decreased by up to $50 \%$ in light, but as coupled denitrification dominated, the effect on $D_{\text {tot }}$ was marginal, with one exception; in May $D_{\mathrm{n}}$ decreased by $60 \%$ in light, coinciding with DIN uptake both in light and dark. At BA, denitrification equaled DIN efflux and did not respond significantly to light, which suggests that $\mathrm{N}$ was less limiting at BA than RA.

\section{Spatial variation of light effect on flux rates}

Although the 2 bays presented seemingly similar systems (cf. Table 1), the MPB were more productive, exerting a stronger control on the sediment system at $\mathrm{R} \AA$ than BA. At $\mathrm{R} \AA$, the magnitude of the light effect was greater (cf. Fig. 2) and more variables were significantly influenced by light (Table 2), which agrees with the higher microphytobenthic GP and NP found at RA. However, the difference between the bays does not apparently result from a greater microphytobenthic biomass at BA (chl a concentrations were similar between bays), nor higher community respiration at BA, which could have balanced the oxygen production. The benthic diatom community appeared to be more active at $\mathrm{R} \AA$, being also reflected by a significant

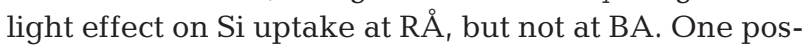
sible explanation for the difference is that other sediment processes, such as faunal activity, exert a stronger control than the MPB on nutrient fluxes at BA. Although the chl a content in the top $5 \mathrm{~mm}$ was similar in the 2 bays, there may have been differences in the vertical distribution of chl a within this interval. A higher density of burrowing infauna at BA (Sundbäck et al. in press) could redistribute algal cells away from the shallow photic zone (generally $<3 \mathrm{~mm}$, Kühl et al. 1994), thereby decreasing microphytobenthic productivity. Thus, animal activity may, to some extent, have overridden the effect of the MPB at BA. Higher effluxes, due to more burrowing fauna at BA (cf. Emmerson et al. 2001) and fewer significant light effects on fluxes and denitrification, also support this explanation.

\section{Can microphytobenthos control the onset of macroalgal growth in spring?}

In our study, we targeted the season most critical for the onset of the growth of the green macroalgal mats. The prerequisite for a microphytobenthic control of the establishment of these mats is that the green algae actually depend on the flux of regenerated nutrients from the sediment rather than on external import of nutrients to the water column of the bay. Such a scenario could prevail when land run-off is low due to dry weather conditions, or when nutrient loads have been decreased as a measure to counteract coastal eutrophication. Our data, although limited, suggest that MPB can under such circumstances delay, or even prevent, the establishment of green-macroalgal mats (cf. Sundbäck et al. 1996).

A microphytobenthic control could apply at $\mathrm{R} \AA$, where MPB activity was high and sediment efflux low, frequently directed into the sediment. Although this bay usually harbours green-macroalgal mats, no such mats developed during the study period. Macroalgal mats, however, did form at BA. Comparing the $\mathrm{N}$-demand of the mats with the measured fluxes out of

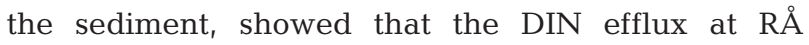
accounted for up to $35 \%$ of the green-algal N-demand, but up to $100 \%$ at BA (Sundbäck et al. in press). Assuming that the main reduction of nutrient efflux in 
light was due to microphytobenthic activity, then this activity apparently turned the sediment from a Nsource to a N-sink at RÅ. Shallow, particularly sandy, sediments have been found to frequently function as $\mathrm{N}$-sinks in spring and summer (e.g. Nilsson et al. 1991, Rizzo et al. 1992, Sundbäck et al. 2000). However, it must also be kept in mind that other factors such as water movement and wind conditions are important factors regulating the occurrence of green-macroalgal mats, as shown in a modelling approach by Stigebrandt \& Eilola (1999).

A second indication of the competitive role of the MBP is that its N-demand can be of the same magnitude as that of the green macroalgae. The calculated mean microphytobenthic demand based on NP at RÅ (3.2 mmol N m$~^{-2} \mathrm{~d}^{-1}$ ) was in fact higher (by a factor of 1.4) than that of growing green-algal mats at $\mathrm{BA}$ $\left(2.3 \mathrm{mmol} \mathrm{N} \mathrm{m}{ }^{-2} \mathrm{~d}^{-1}\right)$. A similar dominance of microphytobenthic $\mathrm{N}$-uptake over macroalgal $\mathrm{N}$-assimilation was found for a lagoon on the coast of Virginia, although the observed microalgal assimilation rates were even higher than we observed (6 to $10.6 \mathrm{mmol} \mathrm{N}$ $\mathrm{m}^{-2} \mathrm{~d}^{-1}$ for MBP vs 3.1 to $9.5 \mathrm{mmolN} \mathrm{m}^{-2} \mathrm{~d}^{-1}$ for macroalgae, McGlathery et al. 2001). At BA, where the sediment system was mainly heterotrophic, the Ndemand of the MPB was at most only $50 \%$ of the green macroalgal demand (cf. Fig. 4a). This suggests that the MPB exerted a strong competition for the DIN pool of the sediment at RA.. It could be argued that the retention time of $\mathrm{N}$ in the MPB is much shorter than in the macroalgal mats. However, previous studies suggest that remineralised $\mathrm{N}$ is rapidly recycled back to the microbiota at the very sediment surface (Lomstein et al. 1998), keeping DIN concentrations in the water column low. In this context, it could also be argued that our calculated macroalgal nutrient demand could be underestimated, as the growth rate is based on only few measuring occasions and the loss rate is not known. However, the growth rates of the Enteromorpha mats in our study are well within the range of growth rates found in field cage experiments on Enteromorpha species from the same region (Pihl et al. 1996, for further discussion see Sundbäck et al. in press).

\section{Balance between the N-retaining and removing processes}

Although our study considered only 1 season and 3 $\mathrm{N}$-removal processes (2 temporary and 1 final), it should still give an idea of the main paths of $\mathrm{N}$ turnover in spring. The role of rooted perennial benthic primary producers (seagrasses) was not included in our study. However, the only occasion when sea- grasses (Ruppia sp.) could have affected the processes to any degree was in late June at RA. Because of a shallow water column, the influence of phytoplankton was negligible, as indicated by the oxygen and nutrient fluxes in the blank cores.

Our results suggest that when the MPB is the only benthic primary producer (RA), it is responsible for the main assimilation of sediment-derived DIN, denitrifiers being of minor importance. This is in accordance with a previous hypothetical conclusion that, in cool shallow microtidal waters where the MPB dominates primary productivity, denitrification plays only a minor role for the removal of $\mathrm{N}$ from the ecosystem, $A: D$ ratios being generally $>5$ (Table 3 in Sundbäck \& Miles 2000 and references therein). Low denitrification rates also apply for areas dominated by seagrass productivity in Scandinavian waters (Risgaard-Petersen et al. 1998, Ottosen et al. 1999). Such high $A: D$ ratios do not apply to cool temperate macrotidal areas in general, such as estuaries in the $\mathrm{UK}$, where the $A: D$ ratio may be $<1$ (Dong et al. 2000), or warmer macrotidal estuaries, such as the Tagus estuary in Portugal (Cabrita \& Brotas 2000). However, this regional difference also reflects a difference in the $\mathrm{N}$-status of these areas. Studied Swedish sites had maximum winter values of $30 \mu \mathrm{mol} \mathrm{NO} \mathrm{NO}_{3}$ (Sundbäck et al. 2000, K. Sundbäck, F. Linares \& A. Miles unpubl.), while maximum water column values of $\mathrm{NO}_{3}$ may be an order of magnitude higher in other European estuaries (e.g. Dong et al. 2000).

Once macroalgal mats were established (BA), they appeared to dominate the N-turnover. This has also been found for the Danish microtidal Limfjorden (Dalsgaard 1999) and shallow coastal lagoons of Virginia (McGlathery et al. 2001). However, the share of denitrification in $\mathrm{N}$-consumption was also higher at BA, equivalent to $75 \%$ of the green-macroalgal assimilation, suggesting that denitrification was a more important pathway of N-removal than if the MPB was the only primary producer (RA). The difference in the $A: D$ balance between the 2 bays also agrees with the hypothesis by An \& Joye (2001) that benthic microalgal production dominates the benthic $\mathrm{N}$ cycle when $\mathrm{N}$ is limiting, denitrification becoming more important when $\mathrm{N}$ is in excess.

The measured hourly rates of total denitrification (4 to $60 \mu \mathrm{mol} \mathrm{m} \mathrm{m}^{-2} \mathrm{~h}^{-1}$ ) are within the lower range reported for other shallow-water coastal sediments (Cabrita \& Brotas 2000 and references therein). However, rates were higher than those previously found for shallow sediments on the west coast of Sweden $l<1$ to $40 \mu \mathrm{mol} \mathrm{m}{ }^{-2} \mathrm{~h}^{-1}$; Sundbäck et al. 2000) and the Baltic Proper $\left(<1\right.$ to $12 \mu \mathrm{mol} \mathrm{m} \mathrm{m}^{-2} \mathrm{~h}^{-1}$; Sundbäck et al. unpubl.). Assuming that oxygen uptake provides a reliable measure of mineralisation rates within the 
sediment, we can roughly estimate the share of mineralised $\mathrm{N}$ that was denitrified from values for community respiration and the $\mathrm{C}: \mathrm{N}$ ratio of the surface sediment (cf. Trimmer et al. 2000). Assuming an $\mathrm{O}_{2}: \mathrm{CO}_{2}$ mean ratio of 1 (see Hulth et al. 1997), then denitrification accounted for, on average, $10 \%$ (range 4 to $18 \%$ ) at R $\AA$ and $20 \%$ (range 9 to 37 ) at BA of the N-mineralisation. These figures are higher than those found by Trimmer et al. (2000) for some harbours in southern England $(<2 \%$ of $\mathrm{N}$-mineralisation), but similar to those found in the Great Ouse estuary (8 to $26 \%$, Nedwell \& Trimmer 1996), which were considered rather high. Thus, in contrast to what has been previously suggested for Scandinavian microtidal shallow-water sediments (Sundbäck \& Miles 2000), denitrification may be a significant $\mathrm{N}$-sink in bays harbouring greenmacroalgal mats on the west coast of Sweden.

\section{CONCLUSIONS}

Microphytobenthos can significantly reduce inorganic nutrient efflux from the sediment during the period that is critical for the onset of the growth of green-macroalgal mats. Thus, microphytobenthos appear to efficiently control the availability of sedimentderived nutrients to the green macroalgae that are in their early growth phase, and hypothetically delay, or even prevent, the onset of the growth of floating macroalgal mats. The prerequisite for this scenario is, however, that green-macroalgal growth depends mainly on sediment efflux of regenerated nutrients, and that other benthic processes, such as high infaunal activity, do not override the microphytobenthic control. Estimates of $\mathrm{N}$-consuming processes show that microphytobenthic $\mathrm{N}$-demand can exceed green-macroalgal $\mathrm{N}$-demand and that denitrification plays only a minor role as an $\mathrm{N}$-sink in autotrophic sediment systems dominated by microphytobenthic primary producers. However, in a net heterotrophic shallow-water system, with no or little net microphytobenthic productivity, a more active fauna, and hence, larger nutrient effluxes, green macroalgal growth is the main $\mathrm{N}$-consuming process, followed closely by denitrification. Thus, denitrification may be a significant $\mathrm{N}$-sink in eutrophicated bays harbouring green-macroalgal mats on the west coast of Sweden.

Acknowledgements. Funding for the project was received from the MISTRA Foundation and the EU-life Algae Project (LIFE96ENV/S/380) co-ordinated by the County Administration of Västra Götaland. We also wish to thank the following funds for valuable support: The Royal Society of Arts and Sciences in Göteborg, the Foundation in Memory of Birgit och Birger Wåhlström and the Captain Stenholm Fund. We thank our colleagues Leif Pihl, Erik Selander and Anders Svenson from the Department of Marine Ecology, and Stefan Hulth and Pia Engtröm from the Department of Analytical and Marine Chemistry for a most inspiring co-operation during the field work at the Kristineberg Marine Research Station, Fiskebäckskil. Lars Gamfeldt ran the statistical tests and Malin Hansson provided help during field sampling.

\section{LITERATURE CITED}

An S, Joye SB (2001) Enhancement of coupled nitrificationdenitrification by benthic photosynthesis in shallow estuarine sediments. Limnol Oceanogr 46:62-74

Cabrita MT, Brotas V (2000) Seasonal variation in denitrification and dissolved nitrogen fluxes in intertidal sediments of the Tagus Estuary. Mar Ecol Prog Ser 202:51-65

Dalsgaard T (1999) Nitrogen cycling in estuaries. Final Scientific Report for NICE-Nitrogen cycling in estuaries: a project under the EU research programme: Marine Science and Technology (MAST III). National Environmental Research Institute, Silkeborg

Dalsgaard T, Nielsen LP, Brotas V, Viaroli P and 11 others (2000) Protocol handbook for NICE - Nitrogen Cycling in Estuaries: a project under the EU research programme: Marine Science and Technology (MAST III). National Environmental Research Institute, Silkeborg

de Jonge VN (1980) Fluctuations in the organic carbon to chlorophyll a ratios for estuarine benthic diatom populations. Mar Ecol Prog Ser 2:345-353

den Hartog C (1994) Suffocation of a littoral Zostera bed by Enteromorpha radiata. Aquat Bot 47:21-28

Dong LF, Thornton DCO, Nedwell DB, Underwood GJC (2000) Denitrification in sediments of the River Colne estuary, England. Mar Ecol Prog Ser 203:109-122

Emmerson MC, Solan M, Ames C, Paterson DM, Raffaelli D (2001) Consistent patterns and the idiosyncratic effects of biodiversity in marine ecosystems. Nature 411:73-77

Fong P, Donohoe RM, Zedler JB (1993) Competition with macroalgae and benthic cyanobacterial mats limits phytoplankton abundance in experimental microcosms. Mar Ecol Prog Ser 100:97-102

Havens KE, Hauxwell J, Tyler AC, Thomas S and 5 others (2001) Complex interactions between autotrophs in shallow marine and freshwater ecosystems: implications for community responses to nutrient stress. Environ Pollut 113:95-107

Henriksen K, Hansen J, Blackburn TH (1980) The influence of benthic infauna on exchange rates of inorganic nitrogen between sediment and water. Ophelia (Suppl) 1:249-256

Hodgkin EP, Birch PB (1986) No simple solution: proposing radical management options for a eutrophic estuary. Mar Pollut Bull 17:399-404

Hulth S, Tengberg A, Landén A, Hall POJ (1997) Mineralization and burial of organic carbon in sediments of the southern Weddel Sea (Antarctica). Deep-Sea Res I 44: 955-981

Isaksson I, Pihl L, Vanmontfrans J (1994) Eutrophicationrelated changes in macrovegetation and foraging of young cod (Gadus-Morhua L) - a mesocosm experiment. J Exp Mar Biol Ecol 177:203-217

Jeffrey DW, Brennan MT, Jennings E, Madden B, Wilson JG (1995) Nutrient sources for in-shore nuisance macroalgae: the Dublin Bay case. Ophelia 42:147-161

Kühl M, Lassen C, Jørgensen BB (1994) Light penetration and light intensity in sandy marine sediments measured with irradiance and scalar irradiance fiber-optic microprobes. Mar Ecol Prog Ser 105:139-148 
Lomstein BA, Jensen AGU, Hansen JW, Andreasen JB, Hansen LS, Berntsen J, Kunzendorf H (1998) Budgets of sediment nitrogen and carbon cycling in the shallow water of Knebel Vig, Denmark. Aquat Microb Ecol 14:69-80

Lorenzen CJ (1967) Determination of chlorophyll and pheopigments: spectrophotometric equations. Limnol Oceanogr 12:343-346

McGlathery KJ, Anderson IC, Tyler AC (2001) Magnitude and variability of benthic and pelagic metabolism in a temperate coastal lagoon. Mar Ecol Prog Ser 216:1-15

Nedwell DB, Trimmer M (1996) Nitrogen fluxes through the upper estuary of the Great Ouse, England: the role of the bottom sediments. Mar Ecol Prog Ser 142:273-286

Nielsen LP (1992) Denitrification in sediment determined from nitrogen isotope pairing. FEMS Microb Ecol 86: $357-362$

Nilsson P, Jönsson B, Lindström Swanberg I, Sundbäck K (1991) Response of a marine shallow-water sediment system to an increased load of inorganic nutrients. Mar Ecol Prog Ser 71:275-290

Österling M, Pihl L (2001) Effects of filamentous green-algal mats on benthic macrofaunal functional feeding groups. J Exp Mar Biol Ecol 263:159-183

Ottosen LDM, Risgaard-Petersen N, Nielsen LP (1999) Direct and indirect measurements of nitrification and denitrification in the rhizosphere of aquatic macrophytes. Aquat Microb Ecol 19:81-91

Pihl L, Magnusson G, Isaksson I, Wallentinus I (1996) Distribution and growth dynamics of ephemeral macroalgae in shallow bays on the Swedish west coast. J Sea Res 35: 169-180

Pihl L, Svenson A, Moksnes PO, Wennhage H (1999) Distribution of green-algal mats throughout shallow soft bottoms of the Swedish Skagerrak archipelago in relation to nutrient sources and wave exposure. J Sea Res 41:281-294

Raffaelli D (2000) Interactions between macro-algal mats and invertebrates in the Ythan estuary, Aberdeenshire, Scotland. Helgol Mar Res 54:71-79

Reay WG, Gallagher DL, Simmons GMJ (1995) Sedimentwater column oxygen and nutrient fluxes in nearshore environments of the lower Delmarva Peninsula, USA. Mar Ecol Prog Ser 118:215-227

Risgaard-Petersen N, Rysgaard S, Nielsen LP, Revsbech NP (1994) Diurnal variation of denitrification and nitrification in sediments colonized by benthic microphytes. Limnol Oceanogr 39:573-579

Risgaard-Petersen N, Dalsgaard T, Rysgaard S, Christensen PB, Borum J, McGlathery K, Nielsen LP (1998) Nitrogen balance of a temperate eelgrass Zostera marina bed. Mar Ecol Prog Ser 174:281-291

Rizzo WM (1990) Nutrient exchanges between the water column and a subtidal benthic microalgal community. Estuaries 13:219-226

Rizzo WM, Lackey GJ, Christian RR (1992) Significance of euphotic, subtidal sediments to oxygen and nutrient cycling in a temperate estuary. Mar Ecol Prog Ser 86:51-61

Editorial responsibility: Kevin Carman,

Baton Rouge, Louisiana, USA
Rysgaard S, Christensen PB, Nielsen LP (1995) Seasonal variation in nitrification and denitrification in estuarine sediment colonized by benthic microalgae and bioturbating infauna. Mar Ecol Prog Ser 126:111-121

Stigebrandt A, Eilola K (1999) Modeling filamentous algae mats in shallow bays. Report by Department of Oceanography for EU-life Algae. No. LIFE96ENV/S380, Task 10, p 27

Sundbäck K, Miles A (2000) Balance between denitrification and microalgal incorporation of nitrogen in microbial sediments, NE Kattegat. Aquat Microb Ecol 22:291-300

Sundbäck K, Jönsson B, Nilsson P, Lindström I (1990) Impact of accumulating drifting macroalgae on a shallow-water sediment system: an experimental study. Mar Ecol Prog Ser 58:261-274

Sundbäck K, Enoksson V, Granéli W, Pettersson K (1991) Influence of sublittoral microphytobenthos on the oxygen and nutrient flux between sediment and water: a laboratory continuous-flow study. Mar Ecol Prog Ser 74: $262-279$

Sundbäck K, Carlson L, Nilsson C, Jönsson B, Wulff A, Odmark S (1996) Response of benthic microbial mats to drifting green-algal mats. Aquat Microb Ecol 10:195-208

Sundbäck K, Miles A, Göransson E (2000) Nitrogen fluxes, denitrification and the role of microphytobenthos in microtidal shallow-water sediments: an annual study. Mar Ecol Prog Ser 200:59-76

Sundbäck K, Miles A, Hulth S, Pihl L, Engström P, Selander E, Svenson A (in press) Importance of benthic nutrient regeneration during initiation of macroalgal blooms in shallow bays. Mar Ecol Prog Ser

Thornton DCO, Underwood GJC, Nedwell DB (1999) Effect of illumination and emersion period on the exchange of ammonium across the estuarine sediment-water interface. Mar Ecol Prog Ser 184:11-20

Thybo-Christesen M, Rasmussen MB, Blackburn TH (1993) Nutrient fluxes and growth of Cladophora sericea in a shallow Danish bay. Mar Ecol Prog Ser 100:273-281

Trimmer M, Nedwell DB, Sivyer DB, Malcolm SJ (2000) Seasonal organic mineralization and denitrification in intertidal sediments and their relationship to the abundance of Enteromorpha sp. and Ulva sp. Mar Ecol Prog Ser 203: $67-80$

Underwood AJ (1997) Experiments in ecology: their logical design and interpretation using analysis of variance. Cambridge University Press, Cambridge

Valiela I, McClelland J, Hauxwell J, Behr PJ, Hersh D, Foreman K (1997) Macroalgal blooms in shallow estuaries: controls and ecophysiological and ecosystem consequences. Limnol Oceanogr 42:1105-1118

Viaroli P, Bartoli M, Bondavalli C, Christian RR (1996) Macrophyte communities and their impact on benthic fluxes of oxygen, sulphide and nutrients in shallow eutrophic environments. Hydrobiologia 329:105-119

Wetzel RG, Likens GE (1991) Limnological analyses, 2nd edn. Springer-Verlag, Berlin

Submitted: April 16, 2002; Accepted: August 5, 2002

Proofs received from author(s): September 27, 2002 